\title{
"Green" Chemicals from Renewable Agricultural Biomass - A Mini Review
}

\author{
Yixiang Xu, Milford A. Hanna* and Loren Isom
}

Industrial Agricultural Products Center, University of Nebraska, Lincoln, NE 68583-0730, USA

\begin{abstract}
Recently, utilization of renewable resources to replace petroleum as a primary feedstock for liquid fuels, chemicals and materials has become a topic of interest around the world. It is intriguing due to rising oil prices, the negative effects of petroleum on the environment and the advantages of renewable resources, such as their abundance and sustainability. Herein, the possibilities for biobased chemicals prepared from renewable resources are reviewed. The most popular feedstocks for commodity and specialty chemicals are carbohydrates as they account for approximately $95 \%$ of the biomass produced annually. The conversion routes, including chemical and biological routes, direct extraction, and selected technical advancements are discussed. Examples of select biochemcials, their conversion pathways from biomass, and their derivatives and potential applications are indentified.
\end{abstract}

Keywords: Green chemicals, biomass, biomass conversion, biobased chemicals, renewable resources.

\section{INTRODUCTION}

Organic chemicals play important roles in our everyday lives. The United States is the largest producer of chemicals in the world, and represents approximately $25 \%$ of the worldwide chemical market [1]. Since the middle of the $20^{\text {th }}$ century, fossil oil and natural gas have served as the main raw material resources for chemicals production [2]. Currently, almost all organic compounds can be derived from seven basic building blocks, including syngas from methane, ethylene, propylene, butanes, butylenes, butadiene, and BTX (which is a mixture of benzene, toluene, and xylene). These building blocks are obtained from natural gas, petroleum and coal [1]. Currently, in the United States, $\sim 13 \%$ of the crude oil is used to produce nonfuel chemicals [3]. There is a growing interest in the replacement of fossil-based chemicals with biochemicals. Biochemicals refer to the chemicals produced from biomass. Several factors, including awareness of finite petroleum resources, availability of renewable resources, environmental imperatives and recent advances in processing technologies, are driving chemical industries to shift their feedstocks from petroleum to renewable counterparts for production of organic chemicals.

It is well known that the reserves of oil, natural gas and coal are vast but still limited. Fossil energy sources will be depleted with their continuous exploitation. In contrast, biomass is a reliable resource for fuels and chemicals in the long term [4]. Supplementing petroleum consumption with renewable biomass resources is of critical importance in sustaining the growth of the chemical industry. The advantages of using biomass rather than petroleum to manufacture chemicals include opportunities for less pollution, no net $\mathrm{CO}_{2}$ contribution to the atmosphere, more biodegradable and sustainable products and, in some cases, lower cost [5]. It has been found that many biomass derived chemicals have economical advantages, particularly for some functionalized

*Address correspondence to this author at the Industrial Agricultural Products Center, University of Nebraska, Lincoln, NE 68583-0730, USA;

E-mail: mhanna1@unl.edu chemicals [6]. In addition, recent advances in process technologies, especially in fermentation technologies such as enzymatic engineering, metabolic engineering and genetic manipulation, provide new opportunities for producing a wide variety of industrial products from renewable plant resources [7-8]. A key to the chemical industries gradual shift toward the use of renewable biomass resources for industrial chemical manufacturing is the implementation of the biorefinery concept [9]. Similar to a petroleum refinery, a biorefinery integrates a variety of processing technologies to produce multiple bioproducts from various biomasses. Such an approach will help maximize the value of the biomass and minimize low or no value byprodcuts $[1,10]$.

Production of green chemicals from renewable resources is a very broad topic. This mini-review focuses mainly on developments in the last couple decades in the areas of renewable biomass as a source of chemicals, possible conversion pathways and products.

\section{POTENTIAL RENEWABLE RESOURCES}

Renewable resources, generally known as biomass, refer to any material having recent biological origin, including plant materials, agricultural crops, and even animal manure [11]. As a naturally abundant resource, biomass is a desirable alternative to petroleum for production of chemicals because of its sustainability and often low cost. Further, biomass, comprised of $\mathrm{C}, \mathrm{H}, \mathrm{O}$, and $\mathrm{N}$, has a chemical composition similar to fossil feedstocks which contain $\mathrm{C}$ and $\mathrm{H}$. As a consequence, products produced from petroleum can be produced from biomass [1]. Currently, the annual worldwide production of biomass is estimated to exceed 100 trillion kilograms. In the United States, the 250 billion kilograms of wasted plant biomass produced each year far exceeds the current total consumption of 100 billion kilograms for organic chemicals, plastic resins, and fibers [7]. However, presently, only $5 \%$ of chemicals are derived from renewable resources [12]. Therefore, there is huge potential for biobased chemicals to share markets with their fossil based counterparts. 
The most popular biomass feedstock for commodity and specialty chemicals production are carbohydrates. Carbohydrates are, by far, the largest bulk of organic compounds on earth and account for approximately $95 \%$ of the biomass produced annually. Carbohydrates exist primarily in the form of polysaccharides, including starch and cellulose [13]. Traditionally, starch has been used as a basic organic raw material by chemical industries. Many bulk chemicals and polymers can be produced by chemical modification or fermentation of starch and its monosaccharide derivative (D-glucose) [14-16]. However, there is a concern about the competition between industrial and food applications of starch. Therefore, in the medium to long term, conversion of lignocellulosics biomass into glucose and xylose using microbes and other biological systems for fuel and biochemical production is more attractive. Cellulosic biomass, or lignocellulosics, refers to woody and herbaceous plants and major crop residues such as sugar cane bagasse, wheat straw, rice straw and corn stover [7]. Lignocellulosic materials are composed mainly of cellulose, hemicellulose and lignin. Most of the biomass on earth is in the form of lignocellulose. Theoretically, lignocellulosic material is an ideal source of raw sugars for industrial processes since it does not affect food supplies and price. Many efforts have been made to utilize biological, thermal, and chemical conversion technologies to convert lignocellulosic biomass to ethanol and chemicals [17-19]. In addition, lignocellulosic materials could be liquefied into chemical intermediates rich in hydroxyl groups [20]. However, different from its starch counterpart, the highly ordered crystalline structure of cellulose itself, together with the protective sheath (lignin and hemicellulose layers) around it, requires some form of pretreatment to open up the structure to effectively convert it to glucose. Pretreatment processing generally includes treating lignocellulosic materials with dilute sulfuric acid, followed by delignification with various organo-solvents, combined dilute alkaline treatment and homogenization, autohydrolysis, and steam explosion [21-25]. Recently, National Renewable Energy Laboratory researchers developed an advanced pretreatment technology that uses a mixture of an organic solvent and water to cleanly fractionate chemical-grade cellulose, hemicellulose sugars, and lignin [26]. Nevertheless, under current conditions, due to technological disadvantages and economic hurdles, including low specific activity and cost of current commercial cellulose enzymes, the use of lignocellulosic materials as a raw material for chemical production has been a distant second contender compared to its starch counterpart.

Besides the above mentioned carbohydrates, oils and fats of vegetable and animal origin are important renewable raw materials for "green" lubricants, surfactants, and alkyd resins in many industrial and pharmaceutical applications. Different non-ionic surfactants have been produced by changing the length of the hydrophobic fatty acid moiety and the degree of polymerization of the hydrophilic part [27]. In addition, a variety of plants, including some flowers such as poppies and rosemary which provide drugs, fragrances and flavors, have been used as a source of fine and specialty chemicals [28].

In order to expand the use of abundantly available renewable resources as the raw materials for chemical production, to reduce our dependence on foreign oil and environ- mental pollution, a detailed examination of conversion pathways is required.

\section{POSSIBLE CONVERSION PATHWAYS}

\section{Chemical Conversions}

Chemical conversions refer to processes which directly convert biomass to chemicals at high temperature and pressure and in the presence of a catalyst. Some bulk chemicals, including levulinic acid and furfural, can be produced by treating biomass at high temperature for specific times in the presence of conventional mineral acid catalysts, such as hydrosulfuric, hydrochloric, and phosphoric acids [29-31]. However, low yield and significant volumes of side products, together with the use of corrosive chemicals, are challenging commercialization and environmental issues.

A thermochemcial process, generally referred to as gasification, partially oxidizes biomass into syngas, a fuel gas mixture consisting of hydrogen, carbon dioxide, nitrogen and carbon monoxide [32]. The syngas can be converted to important chemical intermediates, including methanol, ammonia and oxy-alcohols [33]. However, this route is relatively slow and typically requires large, complicated and expensive equipment [34].

Many efforts have been made to design innovative alternative pathways to effectively convert biomass to chemicals. One area of research has focused on improving the efficiency of catalysts. A novel aqueous phase catalysis process uses robust catalysts and modified carbon supported catalysts developed to convert sugar and organic acids to industrial chemicals at the Pacific Northwest National Laboratory [3536]. McKoon et al. [37] investigated the stability of silicasupport $\mathrm{Ru}$ catalysts in an aqueous phase conversion of glucose to sorbitol. Size and shape-selective zeolites were found to be very valuable catalysts in conversion of biomass to numerous chemicals [38]. These catalysts significantly increase the efficiency of reactions by immobilizing reactants in their matrix structure. Besides research on catalysts, advancement of efficient conversion processes have been reported. A cost-effective two-phase route for the selective dehydration of fructose to remove excess functional groups, and thereby produce hydroxymethylfurfural, a valuable chemical intermediate, were reported by Roman-Leshkov et al. [39].

Jin et al. [40] found that hydrothermal processing was the most promising for the conversion of biomass into acetic acid using supercritical water as a reaction medium. In addition, chemical conversions have been used to convert the chemical intermediates, which were produced from biological conversion, to final chemical products, including tetrahydrofuran and gamma-butyrolactone from 1, 4-diacids (succinic, fumaric, and malic), and 1,3-propanediol from 3hydroxypropionic acid [41-42].

\section{Biological Conversions}

Biological conversions involve the utilization of biological enzymes or living organisms to catalyze the conversion of biomass into specialty and commodity chemicals. Overall, it is considered to be the most flexible method for conversion of biomass into industrial products [7]. Compared to chemical conversions, where high temperatures and pressures are 
involved, operating conditions for biological conversions are relatively mild. Actually, biological conversions are not a new topic, but rather some commercial bulk chemicals, such as ethanol, lactic acid, citric acid and acetone-butanol, have been produced via yeast and bacterial fermentation processes [43-45]. Recently, there has been growing interest in utilization of biocatalysts to convert renewable resources into chemicals, due to high yield and selectivity, and fewer byproducts. However, because of the metabolic restriction in microorganisms, only a few bulk products currently are produced via fermentation [8]. Therefore, development of new technologies to broaden the product spectrum is necessary. Genetic engineering has emerged as a powerful tool for genetic manipulation of multistep catalytic systems involved in cell metabolism [46]. Recombinant DNA technology is used to clone and manipulate gene encoding enzymes in organisms. Recombinant microorganisms, with altered sugar metabolism, are able to ferment sugar to some specialty chemicals, which cannot be produced by the corresponding original stain [8]. For example, catechol and adipic acid were produced from glucose using genetically modified $E s$ cherichia coli. Both glucose and xylose, in cellulosic biomass, have been converted into ethanol by recombinant Saccharomyces yeast [47]. In addition, immobilized enzyme and whole cells have been used to produce biomass-derived chemicals. Huang and Yang [48] produced fumaric acid from glucose and cornstarch by immobilizing Rhizopus Oryzae cells on a rotating fibrous matrix. Hames et al. [49] patented a microbioal process for converting biomass hydrolyzate into fuels and chemicals by absorbing biomass hydrolyzate on solid metal oxide support to fractionate it with fermentation inhibitors, such as lignin-derived compounds, thus improving the products yield. Currently, efforts are continuing to identify, characterize, and even modify enzymes and living organisms and processes so they can better utilize renewable resources to produce structurally diverse and complex chemicals. High yield and selectivity, as wells as minimum waste streams, favor biological conversions as pathways to transform biomass to higher-value chemicals. However, there are still problems with current biological conversions technologies. Sterilization, fermentation stirring, and separation of target products from aqueous systems with low production concentration entail high energy requirements [8]. Further, considerable investment is required to make processes highly efficient and continuous [3]. Therefore, there are research opportunities in the development of new low cost biological conversions technologies to effectively transform biomass into chemicals.

\section{Direct Extraction}

Some commodity and fine chemicals can be extracted directly from biomass. Ferulic acid, a precursor for vanillin, occurs in a relatively high concentration in the form of xylan polysaccharide ester in corn fiber. Shin et al. [50] extracted ferulic acid from corn fibers using novel fungal and bacterial feruloyl esterases. Arabinogalactan and quercerin dehydrate were isolated from larch wood [51]. Vanillin, used in the flavor and fragrance industries, can be recovered by alkaline oxidation of lignin in the presence of a copper catalyst [5253]. Derouane and Powell [54] patented a novel extraction process that used large pore, high silica/alumina ratio zeolites as selective sorbents to remove vanillin from various liquid solutions. Eckert et al. [55] explored a more benign and cost-efficient way to extract vanillin from lignin using a gas-expanded liquid. Gas, typically $\mathrm{CO}_{2}$, was added to an organic solvent, providing the solvent with different and tunable properties such as solubility, transportability and polarity. Compared to traditional solvents, the advantages of using gas-expanded liquids include low operating cost, ease of separation and reduction of the amount of solvent needed. Direct extraction is a promising pathway for utilizing renewable resources, irrespective of scale [2]. From an economic point of view, the extraction of high-value added chemicals from biomass can be the most profitable, but the availability and variety of chemicals are limited.

\section{POTENTAIL PRODUCTS}

Werpy et al. (2004), at the Pacific Northwest National Laboratory and National Renewable Energy Laboratory, identified the potential top 12 value added building-block chemicals from biomass, actually from sugar [56]. They are 1,4-diacids (succinic, fumaric and malic acids), 2,5-furan dicarboxylic acid, 3-hydroxy propionic acid, aspartic acid, glucaric acid, glutamic acid, itaconic acid, levulinic acid, 3hydroxybutyrolactone, glycerol sorbitol, and xylitol/arabinitol. Based on the different conversion pathways, these building-block chemicals, and their derivatives and potential applications, are summarized in Tables $\mathbf{1}$ and $\mathbf{2}$. From the tables, the 12 building-blocking chemicals were converted either biologically or chemically from sugar. All buildingblock chemicals were further converted to a wide spectrum of derivatives through chemical processes, such as reduction, oxidation, dehydration, hydrogenolysis and direct polymerization. Those chemicals can be used widely as solvents, fiber, antifreeze, and new polymers (such as polyesters, polyamides, and polyurethane) with better polymeric properties, than those currently derived from petroleum.

Further, Frost's group at the Michigan State University conducted research on synthesis of benzene-free aromatic chemicals and their derivatives from glucose, which traditionally have been derived from benzene. These aromatic chemicals include phenol [57], catechnol [58], quinic acid and hydroquinone [59], pyrogallol [60], hydroxyhydroquinone [61], phloroglucinol [62], caprolactam [63] and (derivative) adipic acid [64]. Fig. (1) summarizes the synthesis routes of these chemicals from glucose and their possible derivatives. It was found that two steps were involved in preparation of aromatic chemicals from glucose. Typically, glucose first was converted to chemical intermediates by microbial synthesis, followed by chemical conversion of these intermediates into ideal end chemicals.

It is worthy of note that many of the intermediates, whose syntheses generally require some special enzymes which cannot be found in conventional microbes, can be synthesized at this point because DNA recombinant technology allows the transfer of genes for specific chemical forming enzymes in traditional microbial strains.

Beside synthesis of aromatic chemicals from glucose, as discussed above, Haveren et al. [4] discussed the possibility of production of aromatic chemicals from lignin due to the presence of large quantities of aromatic structures in its molecule as well as it being a simple and economic process. A complex mixture of polyhydroxylated and alkylated phe- 
Table 1. Biological Conversion for Chemical Building Blocks, and their Derivates and Potential Application ${ }^{1}$

\begin{tabular}{|c|c|c|c|c|}
\hline Building Block Chemicals & Pathway from Sugar & Derivatives or Derivative Family & Pathways to Derivatives & Potential Application \\
\hline $\begin{array}{l}\text { 1,4-diacids } \\
\text { (Succinic, fumaric, malic) }\end{array}$ & $\begin{array}{l}\text { Fermentation from } \\
\text { Krebs cycle pathways }\end{array}$ & $\begin{array}{l}\text { Butanediol } \\
\text { Tetrahydrofuran (THF) } \\
\gamma \text {-butyrolactone (BL) } \\
\text { Pyrrolidinone } \\
\text { N-methylpyrrolidinone (NMP) } \\
\text { Straight chain polymers }\end{array}$ & $\begin{array}{l}\text { Reduction } \\
\text { Reductive aminations } \\
\text { Direct polymerization }\end{array}$ & $\begin{array}{l}\text { Solvents } \\
\text { Fiber } \\
\text { Green solvent } \\
\text { Water soluble polymers } \\
\text { Fiber }\end{array}$ \\
\hline 3-Hydroxypropionic acid & Fermentation & $\begin{array}{l}\text { 1,3-propane diol } \\
\text { Acrylate Family } \\
\text { acrylic acid, acrylamide }\end{array}$ & $\begin{array}{l}\text { Reduction } \\
\text { Dehydration }\end{array}$ & $\begin{array}{l}\text { Sorona Fiber } \\
\text { Contact lenses } \\
\text { Diapers }\end{array}$ \\
\hline Aspartic acid* & $\begin{array}{l}\text { Fermentation or } \\
\text { Enzymatic conversion of } \\
\text { oxaloacetate in the } \\
\text { Krebs cycle }\end{array}$ & $\begin{array}{l}\text { Amine butanediol } \\
\text { Amine tetrahydrofuran } \\
\text { Amine- } \gamma \text {-butyrolactone } \\
\text { Aspartic anhydride } \\
\text { Polyaspartic }\end{array}$ & $\begin{array}{l}\text { Reduction } \\
\text { Dehydration } \\
\text { Direct polymerization }\end{array}$ & $\begin{array}{l}\text { Amino analogs of } \mathrm{C} 4 \\
1,4 \text { dicarboxylic acid } \\
\text { New area } \\
\text { New area }\end{array}$ \\
\hline Glutamic acid & Fermentation & $\begin{array}{l}\text { Diols (1,5-pentandiol) } \\
\text { Diacids (Glutaric acid) } \\
\text { Aminodiol (5-amino-1- } \\
\text { butanol, glutaminol ect) }\end{array}$ & Reduction & $\begin{array}{l}\text { Monomers for } \\
\text { polyesters and } \\
\text { polyamides }\end{array}$ \\
\hline Itaconic acid & $\begin{array}{l}\text { Aerobic fungal fermen- } \\
\text { tation }\end{array}$ & $\begin{array}{l}\text { Methyl butanediol } \\
\text { Methyl THF } \\
\text { Methyl- } \gamma \text {-BL } \\
\text { Methyl Pyrrolidinone } \\
\text { Methyl NMP } \\
\text { Polyitaconic }\end{array}$ & $\begin{array}{l}\text { Reduction } \\
\text { Direct } \\
\text { polymerization }\end{array}$ & $\begin{array}{l}\text { New useful properties } \\
\text { for butanediol, THF, } \\
\text { and butyrolactone } \\
\text { New Polymers }\end{array}$ \\
\hline Glycerol* & $\begin{array}{l}\text { Enzymatic transesterifi- } \\
\text { cation }\end{array}$ & $\begin{array}{l}\text { Glyceric acid } \\
\text { PLA analogs } \\
\text { Propylene glycol } \\
\text { 1,3-propanediol } \\
\text { Branched polyesters and polyols }\end{array}$ & $\begin{array}{l}\text { Oxidation } \\
\text { Hydrogenolysis } \\
\text { Direct polymerization }\end{array}$ & $\begin{array}{l}\text { Polyerster fibers with } \\
\text { new properties } \\
\text { PLA with better } \\
\text { polymeric properties } \\
\text { Antifreeze, } \\
\text { humecrtant } \\
\text { Sorona fiber } \\
\text { Unstaturated polyure- } \\
\text { thane resin for } \\
\text { Insulation }\end{array}$ \\
\hline
\end{tabular}

${ }^{\mathrm{I}}$ From Werpy et al. (2004).

*Indicates the building block chemicals also are produced by chemical conversion shown in Table 2 .

nol compounds were formed by cracking lignin with a high temperature thermal process. Although currently there is a challenge in upgrading these mixtures to a higher content of phenol, production of phenol from lignin still is a long-term option.

Currently, there is also a growing interest in synthesis of ethylene from renewable resources. Arenamnart and Trakarnpruk [65] and Takahara et al. [66] converted ethanol to ethylene using dealuminated mordenite, zeolites and silicaalumina catalysts. Further, photosynthetic conversion of carbon dioxide to ethylene by recombinant cyanobacterium Synechococcus sp. PCC 7942 was reported by Sakai et al. [67].

The products listed here represent only a small portion of the biochemicals made by different research groups around the world. Efforts to expand the spectrum of chemicals derived from renewable resources are continuing.

\section{CONCLUSIONS}

The fossil fuel crisis and environmental concerns have encouraged scientist to explore new resources and pathways for chemicals production. Low cost and sustainability, together with chemical compositions similar as fossil feedstocks, render biomass a promising raw material for production of biochemicals. Technological advancements, including biorefineries, heterogeneous catalysts and genetic engineering, guarantee development of green chemicals from biomass. In the mid- to long- term, biochemicals will share markets with petroleum-based chemicals and ultimately replace them as biochemicals become price competitive. 
Table 2. Chemical Conversion for Building Blocks Chemicals, their Derivates and Potential Application ${ }^{1}$

\begin{tabular}{|c|c|c|c|c|}
\hline Building Block Chemicals & Pathway from Sugar & Derivatives or Derivative Family & Pathways to Derivatives & Potential Application \\
\hline $\begin{array}{l}2,5 \text {-furan dicarboxylic acid } \\
\text { (FDCA) }\end{array}$ & $\begin{array}{l}\text { Oxidative dehydration } \\
\text { of C6 sugars }\end{array}$ & $\begin{array}{l}\text { Diols and aminations } \\
\text { Levulinic and succinic acids } \\
\text { Polyethylene } \\
\text { Terephthalate analogs } \\
\text { Furanoic polyamines }\end{array}$ & $\begin{array}{l}\text { Reduction } \\
\text { Direct polymerization }\end{array}$ & $\begin{array}{l}\text { New polyester and nylon } \\
\text { All uses of succinic and } \\
\text { levulinic } \\
\text { Furanoic polyesters for } \\
\text { bottles and films } \\
\text { Polyamide for nylons }\end{array}$ \\
\hline Glucaric acid & $\begin{array}{l}\text { Nitric acid oxidation } \\
\text { of starch } \\
\text { Catalytic oxidation of } \\
\text { starch with bleach }\end{array}$ & $\begin{array}{l}\text { Lactone } \\
\text { Polyglucaric ester } \\
\text { and amides }\end{array}$ & $\begin{array}{l}\text { Dehydration } \\
\text { Direct polymerization }\end{array}$ & $\begin{array}{l}\text { Solvents } \\
\text { Nylons or different } \\
\text { properties }\end{array}$ \\
\hline Aspartic acid* & $\begin{array}{l}\text { Amination of fumaric } \\
\text { acid with ammonia }\end{array}$ & Same as Table 1 & Same as Table 1 & Same as Table 1 \\
\hline Levulinic acid & $\begin{array}{l}\text { Acid catalyzed dehy- } \\
\text { dration and decompo- } \\
\text { sition of cellulosics } \\
\text { and sugars }\end{array}$ & $\begin{array}{l}\text { Methyl tetrahydrofuran } \\
\gamma \text {-butyrolactone } \\
\text { Actetyl acrylates } \\
\text { Acetic-acrylic succinic } \\
\text { acids } \\
\text { Diphenolic acid }\end{array}$ & $\begin{array}{l}\text { Reduction } \\
\text { Oxidation } \\
\text { Condensation }\end{array}$ & $\begin{array}{l}\text { Fuels oxygenates } \\
\text { Solvents } \\
\text { Copolymerization with } \\
\text { other monomers } \\
\text { Replacement of } \\
\text { bisphenol for } \\
\text { polycarbonate }\end{array}$ \\
\hline 3-Hydroxy-butyrolactone & $\begin{array}{l}\text { Oxidative degradation } \\
\text { of starch }\end{array}$ & $\begin{array}{l}\text { Furans, Analogs of pyrrolidones } \\
\text { Amino analogs to tetrahydrofuran }\end{array}$ & $\begin{array}{l}\text { Reduction } \\
\text { Direct polymerization }\end{array}$ & $\begin{array}{l}\text { Solvents } \\
\text { Amino analogs to } \\
\text { lycra fibers }\end{array}$ \\
\hline Glycerol* & $\begin{array}{l}\text { Transesterification of } \\
\text { oils }\end{array}$ & Same in Table $\mathbf{1}$ & Same in Table 1 & Same in Table $\mathbf{1}$ \\
\hline Sorbitol & $\begin{array}{l}\text { Hydrogenation of } \\
\text { glucose }\end{array}$ & $\begin{array}{l}\text { Isosorbide, anhydrosugars } \\
\text { Propylene glycol, lactic } \\
\text { acid } \\
\text { Branched polysaccharides }\end{array}$ & $\begin{array}{l}\text { Dehydration } \\
\text { Hydrogenolysis } \\
\text { Direct polymerization }\end{array}$ & $\begin{array}{l}\text { PET like polymers } \\
\text { Antifreeze, PLA } \\
\text { Water soluble polymers }\end{array}$ \\
\hline Xylitol/arabinitol & $\begin{array}{l}\text { Hydrogenation of } \\
\text { sugars or extraction } \\
\text { from biomass pre- } \\
\text { treatment processes }\end{array}$ & $\begin{array}{l}\text { Xylaric and xylonic acids } \\
\text { Arabonic and Arabinoic acids } \\
\text { Polyols (propylene and ethylene } \\
\text { glycols), lactic acid } \\
\text { Xylitol, xylaric, xlyonic, polyes- } \\
\text { ters and nylons }\end{array}$ & $\begin{array}{l}\text { Oxidations } \\
\text { Hydrogenolysis } \\
\text { Direct polymerization }\end{array}$ & $\begin{array}{l}\text { New uses } \\
\text { Antifreeze, UPRs } \\
\text { New polymer }\end{array}$ \\
\hline
\end{tabular}




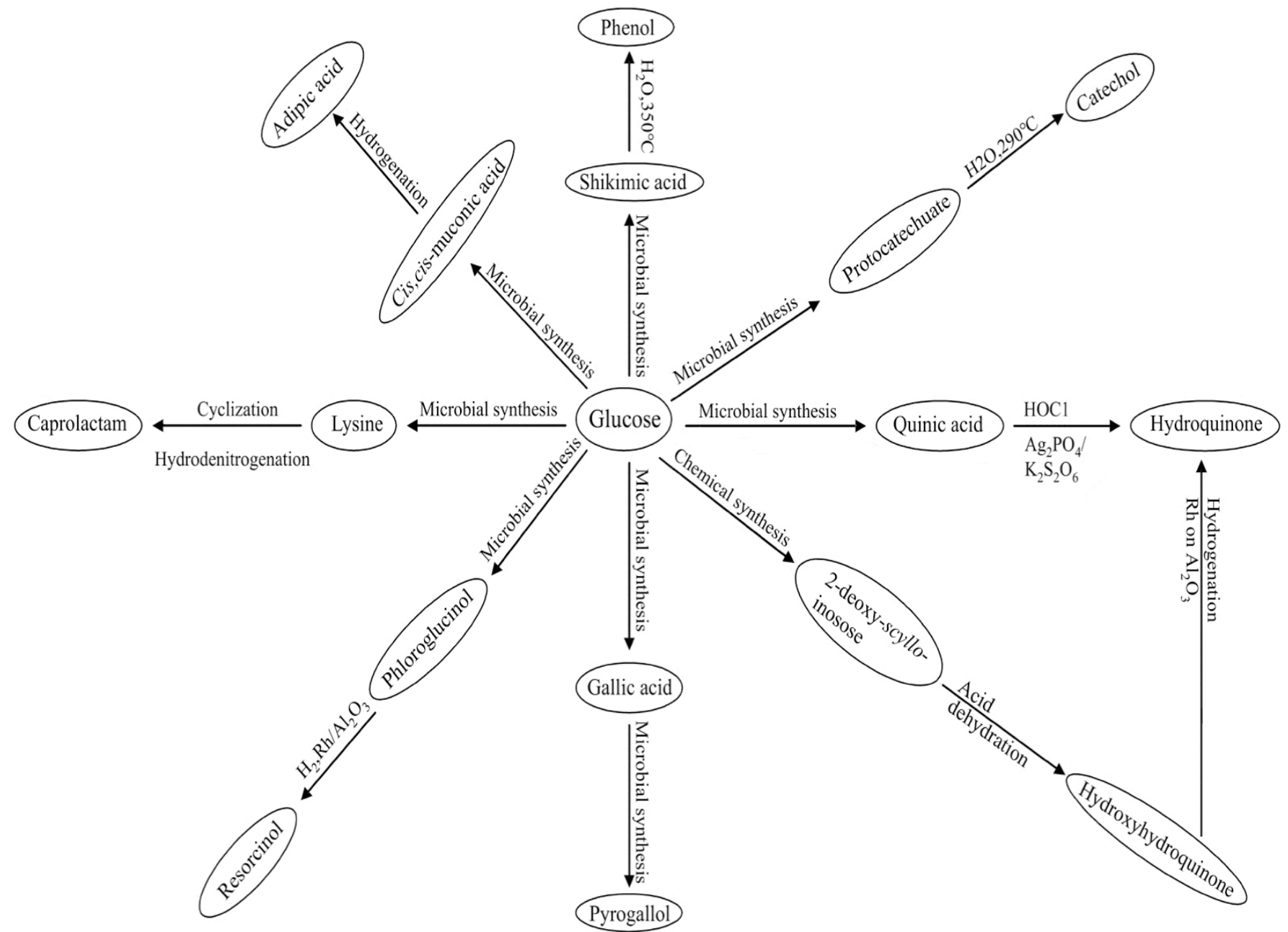

Fig. (1). Benzene-free aromatic chemicals and their synthesis route from glucose.

\section{ACKNOWLEDGEMENTS}

The authors appreciate the financial support provided by Nebraska Corn Development, Utilization and Marketing Board.

\section{REFERENCES}

[1] DOE/SSEB. Biochemicals. Fact Sheet; 2006 [cited 2008 Feb 10]. Available from: http://www.arkansasrenewableenergy.org/fact $\%$ 20sheets/Biochemicals.pdf

[2] Narodoslawsky M, Niederl-Schmidinger A, Halasz L. Utilizing renewable resources economically: new challenges and chances for process development. J Clean Prod 2008; 16: 164-70.

[3] Dodds DR, Gross RA. Chemicals from biomass. Science 2007; 318: 250-1.

[4] Haveren Jv, Scott EL, Sanders J. Bulk chemicals from biomass. Biofuels Bioprod Bioref 2008; 2: 41-57.

[5] Gessa G, Trifiro F. The green revolution for chemistry actuality and perspectives [cited 2008 Feb 4]. Available from: http://gic.istm.cnr.it/uploads/media/trifiro_the_green_revolution for_chemistry.pdf

[6] Brehmer B. Biobased chemicals: today not tomorrow, the valorisation of functionalized chemicals from biomass resources compared to the conventional fossil production route. Abstract at Renewable Resources and Biorefineries Conference, Ghent, Belgium, September 19-21, 2005.
[7] Dale BE. 'Greening' the chemical industry: research and development priorities for biobased industrial products. J Chem Technol Biotechnol 2003; 78: 1093-103.

[8] Danner H, Braun R. Biotechnology for the production of commodity chemicals from biomass. Chem Soc Rev 1999; 28: 395-405.

[9] Frost JW, Draths KM. Biocatalytic syntheses of aromatics from Dglucose: renewable microbial sources of aromatic compounds. Annu Rev Microbiol 1995; 49: 557-79.

[10] Ohara H. Biorefinery. Appl Microbiol Biotechnol 2003; 62: 474-7.

[11] Crocker M, Crofcheck C. Biomass conversion to liquid fuels and chemicals. Energeia 2006; 17(6): 1-3.

[12] Lucia LA, Argyropoulos DS, Adamopoulos L, Gaspar AR. Chemicals and energy from biomass. Can J Chem 2006; 84: 960-70.

[13] Lichtenthaler FW, Mondel S. Perspectives in the use of low molecular weight carbohydrates as organic raw materials. Pure Appl Chem 1997; 69(9): 1853-66.

[14] Wilpiszewska K, Spychaj T. Chemical modification of starch with hexamethylene diisocyanate derivatives. Carbohydr Polym 2007; 70 (3): 334-40.

[15] Uwda S, Zenin CT, Monteiro DA, Park YK. Production of ethanol from raw cassava starch by a nonconventional fermentation method. Biotechnol Bioeng 1981; 23(2): 291-9.

[16] Kim BS, Chang HN. Production of poly (3-hydroxybutyrate) from starch by Azotobacter chroococcum. Biotechnol Lett 1998; 20 (2): 109-112.

[17] Wu A, Lee YY. Nonisothermal simultaneous saccharification and fermentation for direct conversion of lignocellulosic biomass to ethanol. Appl Biochem Biotechnol 1998; 70-72: 479-92. 
[18] Sun Y, Cheng J. Hydrolysis of lignocellulosic materials for ethanol production: a review. Biores Technol 2002; 83(1): 1-11.

[19] Wyman CE. Potential synergies and challenges in refining cellulosic biomass to fuels, chemicals, and power. Biotechnol Prog 2003; 19: 254-262.

[20] Liang L, Mao Z, Li Y, Wan C, Wang T, Zhang L, Zhang L. Liquefaction of crop residues for polyol production. BioResources 2006; 1(2): 248-56.

[21] Lee YH, Robison CW, Moo-Young M. Evaluation of organosolv processes for the fractionation and modification of corn stover for bioconversion. Biotechnol Bioeng 1987; 29 (5): 572-81.

[22] Li Y, Ruan R, Chen PL, et al. Enzymatic hydrolysis of corn stover pretreated by combined dilute alkaline treatment and homogenization. Trans ASAE 2004; 47(3): 821-5.

[23] Vegas R, Alonso JL, Dominguez H, Parajo JC. Processing of rice husk autohydrolysis liquors for obtaining food ingredients. J Agric Food Chem 2004; 52: 7311-7.

[24] Nabarlatz D, Farriol X, Montane D. Autohydrolysis of almond shells for the production of xylo-oligosaccharides: product characteristics and reaction kinetics. Ind Eng Chem Res 2005; 44: 774655.

[25] Ramos LP. The chemistry involved in the stream treatment of lignocellulosic materials. Quim Nova 2003; 26(6): 863-71.

[26] National Rwable Energy Laboratory. Biochemical conversion technologies-projects. [updated 2007 Nov 6; cited 2008 Feb 20]. Available from: http://www.nrel.gov/biomass/proj_biochemical_ conversion.html

[27] Jose CM, Corma A, Hamid SBA, Iborra S, Mifsud M. Chemicals from biomass derived products: synthesis of polyoxyethyleneglycol ester from fatty acid methyl esters with solid basic catalysts. Green Chem 2006; 8: 524-32.

[28] Coombs J, Hall K. Chemicals and polymers from biomass. Renew Energy 1998; 15: 54-9.

[29] Win DT. Furfural? Gold from garbage. Au J T 2005; 8(4): 185-90.

[30] Fang Q, Hanna MA. Experimental studies for levulinic acid production from whole kernel grain sorghum. Biores Technol 2002; 81: $187-92$.

[31] Takeuchi Y, Jin F, Tohji K, Enomoto H. Acid catalytic hydrothermal conversion of carbohydrate biomass into useful substances. J Mater Sci 2008; 43: 2472-5.

[32] Bain RL. Thermochemical technologies for conversion of biomass to fuels and chemicals. Presened at Rice University, Houston, TX. Sept 26, 2006. Available from: http://www.rice.edu/energy/ publications/eventpres/biofuels/Biofuels_Bain_092606.pdf

[33] Phillips G. Gasfication-a versatile solution for clean power, fuels \& petrochemicals \& an opportunity to reduce $\mathrm{CO}_{2}$ emissions. Presented at $7^{\text {th }}$ World congress of chemical engineering. Glasgow, Scotland. July 10-14, 2005

[34] Salge JR, Dreyer BJ, Dauenhauer PJ, Schmidt LD. New process to produce completely renewable fuels and chemicals. Scitizen [Updated 2006 Nov 10; cited 2008 Feb 20]. Available from: http://scitizen.com/screens/blogPage/viewBlog/sw_viewBlog.php?i dTheme $=14 \&$ idContribution $=235$

[35] Elliott DC, Darab JG. Catalytic hydrothermal reductions [cited 2008 Feb 19]. Available from: http://www.pnl.gov/biobased/ docs/catalysis_fy 99. pdf

[36] Pacific Northwest National Laboratory. Modified carbon supports for aqueous phase catalysis-applications for the conversion of glucose and fermentation products to value-added chemicals. [updated 2008 May; cited 2008 Feb 19]. Available from: http://www.pnl. gov/biobased/completed.stm

[37] McKoon EP, Ketchie WC, Oleshko VP, Davis RJ. Stability of silica-supported Ru catalysts for glucose hydrogenation to sorbitol. Presented at AIChE Annual Meeting, Cincinnati, OH. Oct 30-Nov $4,2005$.

[38] Tsao GT. Zeolite in biomass energy. Energy conversion engineering conference, IECEC-90. Proc. 25th Intersociety, 1990; 3: 505-8.

[39] Roman-Leshkov Y, Chheda JN, Dumesic JA. Phase modifiers promote efficient production of hydroxymethylfurfural from fructose. Science 2006; 321: 1933-7.
[40] Jin F, Zhou Z, Kishta A, Enomoto H. Hydrothermal conversion of biomass into acetic acid. J Mater Sci 2006; 41: 1495-500.

[41] Zimmermann H, Brenner K, Scheiper H-J, Sauer W, Hartmann H, inventors; Preparation of tetrahydrofuran and gammabutyrolactone. United States patent US 5319111. 1994 Jun.

[42] Meng X, Abraham TW, Tsobanakis P, inventors; Process for preparation of 1,3-propanediol. United States patent US 7126034. 2006 Oct.

[43] Huang LP, Jin B, Lant P, Zhou J. Simultaneous saccarification and fermentation of potato starch wastewater to lactic acid by Rhizopus oryzae and Rhizopus arrhizus. Biochem Eng J 2005; 23: 265-76.

[44] Atsushi S, Somsak S, Kohtaro K, Shoji U. Direct production of citric acid from Starch by a 2-deoxygluxose-resistant mutant strain of Aspergillus niger. J Ferment Bioeng 1996; 81(4): 320-3.

[45] Ezeji T, Qureshi N. Blaschek H. Production of acetone butanol from liquefied corn starch, a commercial substrate, using Clostridium beijerinckii coupled with product Recovery by gas stripping. J Ind Microbiol Biotechnol 2007; 34: 771-7.

[46] Zha W, Shao Z, Frost JW, Zhao H. Rational pathway engineering of type I fatty acid synthase allows the biosynthesis of triacetic acid lactone from D-glucose in vivo. J Am Chem Soc 2004; 126: 4534-5.

[47] Anastas PT, Kirchhoff MM. Origins, current status, and future challenges of green chemistry. Acc Chem Res 2002; 35: 686-94.

[48] Huang H, Yang ST. Fumaric acid production from glucose and cornstarch by immobilized cells of Rhizopus oryzae in a rotating fibrous bed bioreactor. Presented at AIChE Annual Meeting, Cincinnati, OH. Oct 30-Nov 4, 2005.

[49] Hames B, Sluiter AD, Hayward TK, Nagle NJ, inventors; Process for the conversion of aqueous biomass hydrolyzate into fuel and chemicals by the selective removal of fermentation inhibitors. United States patent US6737258B2. 2004 May.

[50] Shin HD, McClendon S, Taylor F, Chen RR. Enzymatic extraction of ferulic acid from agriculture waste for high-valued products. Paper presented at AIChE Annual Meeting, Cincinnati, OH. Oct $30-$ Nov 4, 2005.

[51] Kuznetsova SA, Danilov VG, Kuznetsov BN, Taraban'Ko VE Pervyshina EP, Alexaandrova NB. Fine chemicals from larch wood biomass [cited $2008 \mathrm{Feb} 20]$. Available from: http://www.brdisol utions.com/pdfs/bcota/abstracts/26/z120.pdf

[52] Azadbakht M, Ebrahimzadeh MA, Koolayan S. Preparation of lignin from wood dust as vanillin source and comparison of different extraction methods. Int J Biol Biotechnol 2004; 1 (4): 535-7.

[53] Kuznetsov BN. Application of catalysts for producing organic compounds from plant biomass. React Kinet Catal Lett 1996; 57(2): 217-25.

[54] Derouane EG, Powell RA, inventors; Vanillin extraction process using large pore, high silica/alumina ratio zeolites. United States patent US4652684. 1987 Mar.

[55] Ecket C, Liotta C, Ragauskas A, et al. Tunable solvents for fine chemicals from the biorefinery. Green Chem 2007; 9: 545-548.

[56] Werpy T, Petersen G, Aden A, et al. Top value added chemicals from biomass. Volume 1: result of screening for potential candidates from sugar and synthesis gas; 2004 [cited 2008 Feb 24]. Available from: http://www1.eere.energy.gov/biomass/pdfs/35523. pdf

[57] Gibson JM, Thomas PS, Thomas JD, et al. Benzene-free synthesis of phenol. Angew Chem Int Ed 2001; 40(10): 1945-1948.

[58] Li W, Xie D, Frost JW. Benzene-free synthesis of catechol: interfacing microbial and chemical catalysis. J Am Chem Soc 2005; 127 : 2874-2882

[59] Ran N, Knop DR, Draths KM, Frost JW. Benzene-free synthesis of hydroquinone. J Am Chem Soc 2001; 123: 10927-10934.

[60] Kambourakis S, Draths KM, Frost JW. Synthesis of gallic acid and pyrogallol from Glucose from glucose: replacing natural product isolation with microbial catalysis. J Am Chem Soc 2000; 122: 9042-9043.

[61] Hansen CA, Frost JW. Deoxygenation of polyhydroxybenzenes: an alternative strategy for benzene-free synthesis of aromatic chemicals. J Am Chem Soc 2002; 124: 5926-5927. 
[62] Frost JW, inventor; Biosynthesis of phloroglucinol and preparation of 1,3-dihydroxybenzene therefrom. United States patent US 2007/0178571 A1. 2007 Aug.

[63] Frost JW, inventor; Synthesis of caprolactam from lysine. United States patent US 2007/0149777 A1. 2007 Jan.

[64] Niu W, Draths KM, Frost JW. Benzene-free synthesis of adipic acid. Biotechnol Prog 2002; 18: 201-11.

[65] Arenamnart S, Trakarnpruk W. Ethanol conversion to ethylene using metal-mordenite catalysts. Int J Appl Sci Eng 2006; 4(1): 2132.
[66] Takahara I, Saito M, Inaba M, Murata K. Dehydration of ethanol into ethylene over solid acid catalysts. Catal Lett 2005; 105(3-4): 249-52.

[67] Sakai M, Ogawa T, Matsuoka M, Fukuda H. Photosynthetic conversion of carbon dioxide to ethylene by the recombinant cyanobacterium, synechococcus sp. PCC 7942, which harbors a gene for the ethylene-forming enzyme of Pseudomonas syringae. $\mathrm{J}$ Ferment Bioeng1997; 84(5): 434-43.

(C) Xu et al.; Licensee Bentham Open.

This is an open access article licensed under the terms of the Creative Commons Attribution Non-Commercial License (http://creativecommons.org/licenses/by$\mathrm{nc} / 3.0 /$ ) which permits unrestricted, non-commercial use, distribution and reproduction in any medium, provided the work is properly cited. 